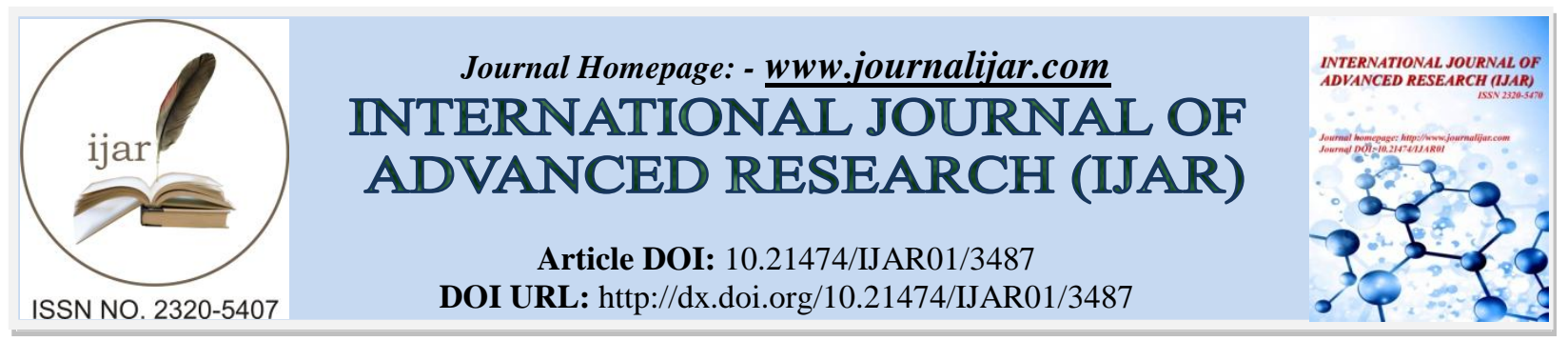

RESEARCH ARTICLE

\title{
IN VITRO ANTI INFLAMMATORY AND ANTI MICROBIAL PROPERTIES OF ALLOPHYLUS SERRATUS LEAF EXTRACTS.
}

Kero Jemal, B.V Sandeep and Sudhakar Pola.

\section{Manuscript Info}

Manuscript History

Received: 07 January 2017

Final Accepted: 09 February 2017

Published: March 2017

Key words:-

Anti microbial; Antibacterial; Antiinflammatory; Allophylus serratus; leaf extract.

\begin{abstract}
Allophylus serratus is a local medicinal plant used traditionally for the treatment of diarrhea, inflammation, ulcer, elephantiasis and gastro intestinal disorders. The leaf extracts of this plant were assessed for in vitro anti-inflammatory and antibacterial activities. The in vitro anti inflammatory activity assay of leaf extracts of Allophylus serratus were evaluated by Human Red Blood Cells membrane stabilization, inhibition of protein denaturation and protease inhibition methods. The anti microbial activity of leaf extracts were evaluated by agar well diffusion method against four bacterial and two fungi species. The membrane stabilization anti inflammatory test showed that, the methanolic leaf extracts exhibited highest membrane stabilizing activity of $77.64 \pm 0.78$ and $74.77 \pm 0.66$, compared to that of standard Diclofenac sodium which exhibited $92.65 \pm 0.56 \%$ and $89.73 \pm 1.18$ at $1000 \mu \mathrm{g} / \mathrm{ml}$ and $800 \mu \mathrm{g} / \mathrm{ml}$ concentrations respectively. In inhibition of protein denaturation, $400 \mu \mathrm{g} / \mathrm{ml}$ methanolic extract showed maximum protection $70.73 \%$ and standard drug provided $93.50 \%$ protection. But at $1000 \mu \mathrm{g} / \mathrm{ml}$ the percent inhibition of protein denaturation increased to $95.93 \%$. More over protease inhibition test showed maximum inhibition $(67.63 \%)$ at $100 \mu \mathrm{g} / \mathrm{ml}$ concentrations by ethyl acetate extract. In anti inflammatory test, all extraction showed concentration dependent response. In anti microbial activity test the water, methanolic and ethyl acetate extracts were more effective against Escherichia coli and Staphylococcus aureus. Ethyl acetate extract also showed high activity against Bacillus sabtilis $(20 \pm 0.00 \mathrm{~mm})$. Chloroform and petroleum ether extracts showed high zone of inhibition $(20 \pm 0.17$ and $22 \pm 0.09 \mathrm{~mm}$ respectively) against Pseudomonas aeruginosa but no activity against the rest tested bacterial strains. All the extracts did not show any activity against tested fungal species. The results of this study therefore revealed that leaf extracts of Allophylus serratus possess anti inflammatory and anti bacterial activity which justify the use of this plant in the treatment of bacterial infections and inflammation.
\end{abstract}

Copy Right, IJAR, 2017,. All rights reserved.

\section{Introduction:-}

Plants are the main sources of therapeutic agents for treatment of various alignments and diseases since ancient time. For example, in Africa, about $80 \%$ of the population depends on medicinal plants in managing various endemic 
forms of infections (Agyare et al., 2009). Over the past years, many medicinal plants have been proved to be a remarkable source of therapeutic agents and have therefore given attention in most research centers in the world (Iwu et al., 1999; Agyare et al., 2013). The advantage of using medicinal plants is that they are natural and have no side effects. According to World Health Organization, medicinal plants would be the best source of a variety of important drugs. Therefore, to better understand their efficacy, safety and properties, such plants should be properly investigated (Nascimento et al., 2000). There are many reports on the use of medicinal plants as anti inflammatory and anti microbial agents. This is due to the presence of chemical compounds in plants that suppress inflammatory reactions and the reproduction and growth of micro organisms.

Inflammation and pain are our body's natural reaction to injury caused by infectious agents, burn, toxic or physical, chemical or traumatic damages (Battu et al., 2011). The reaction comprises systemic and local responses (Mohamed et al., 2011). One purpose of inflammation is to limit or eliminate the spread of injurious agent and protect the body site of an injury. There are different components to an inflammatory response such as a complex array of enzyme activation, mediator release, cell migration, tissue breakdown and repair. These responses are aimed at host defense and usually activated in most disease condition.

Modern drugs such as narcotics (e.g. opioids), non-narcotics (e.g. salicylates) and corticosteroids (e.g. hydrocortisone) which are in use presently for the management of inflammatory conditions are toxic and have well known side effects such as gastric ulcers and redistribution of body fat. In addition, these drugs are very expensive. On the other hand many medicinal plants had been used since long time as anti inflammatory without any side effects. At present, much attention has been given in the searching of medicinal plants with anti-inflammatory activity which is not only without side effects but also cheap. These medicinal plants used as anti inflammatory activity may lead to the discovery of new therapeutic agent that is not only used to suppress the inflammation but also used in diverse disease conditions where the inflammation response is amplifying the disease process.

Microorganisms such as bacteria and fungi cause various diseases in humans. To treat these microbial infections, various antimicrobial drugs have been discovered. Due to the indiscriminate use of these commercial antimicrobial drugs, resistance to these drugs by microorganisms has been developed and increased day by day (Davis, 1994; Ahamad, 1998; Karuppiah and Mustaffa, 2013). The number of resistant microorganisms to these antimicrobial agents is increases exponentially. Therefore it is very important to understand the genetic mechanisms of resistance, to screen medicinal plants for the identification and development of newer and cost effective anti microbial agents to treat infections caused by resistant microorganisms. Medicinal plants have also been used as anti microbial agents. Many medicinal plants have been used to treat microbial infections because of their antimicrobial properties, which are due to compounds synthesized in the secondary metabolism of the plant. Therefore, such plants should be investigated to better understand their properties, safety and efficiency (Doughari et al. 2008 ) .

Allophylus serratus (Roxb.) Kurz, (Synonym Allophylus cobbe Raeuschel; Allophylus edulis Radlk) (Dharmani and Palit, 2005), commonly known as Tippani in Hindi, belongs to the family Sapindaceae. It is a small tree or shrub found all over different parts of India. Traditionally this plant carries a strong ethno-pharmacological background and has been used as anti inflammatory, anti ulcer, to treat elephantiasis, oedma, and fracture of bones and gastrointestinal disorders such as diarrhea, anorexia and dyspepsia( Umashanker et al., 2011; Gupta and Tandon, 2004). Dharmani et al., (2005) and Kumar et al., (2010), reported that the ethanolic extract of Allophylus serratus has potential anti ulcerogenic and anti osteoporotic activities respectively. The leaves are used to reduce fever, to relieve rashes, promote lactation, to treat colic to relieve stomach aches, as antiulcer and to reduce piles (Umashanker and Shruti, 2011; Devi et al., 2013). The roots of this plant contain tannin and are considered astringent and used for treating nose bleeding, diarrhea and rheumatic pains (Umashanker and Shruti, 2011).

The presences of different phytochemicals such as steroids, glycosides, flavonoids, alkaloids and phenolics in this species have been reported (Sanmuga et al., 2012). Phytochemical screening and Pharmacognostic studies of Allophylus serratus showed the presence of various chemical compounds in different parts of the plant. Leaves of the plant contain B-sitosterol. They also contain phenacetamide, a chemical known for its antiulcer activity ( Rastogi and Mehrotra, 1995). The presence of Quercetin, Pinitol, Luteolin-7-O-B-D-glucopyranoside, rutin, apigenin-4-OB-D-glucosid also reported by Kumar et al., (2010). The aim of present study is to evaluate the in vitro antiinflammatory activity and antimicrobial efficacy of leaves extracts of Allophylus serratus. 


\section{Materials and Methods:- \\ Plant material:-}

Leaves of Allophylus serratus were collected between September and December 2015, from Andhra University, Visakhapatnam, India. The plant was identified and authenticated by Dr. Bodaih Padal, taxonomist, Department of botany, Andhra University, Visakhapatnam. The voucher specimens (21921) were deposited in the herbarium, College of Science and Technology, Department of Botany, Andhra University, India.

\section{Preparation of plant leaves extracts:-}

The leaves of Allophylus serratus were washed with distilled water and shade dried in dark for three weeks to a constant weight. The dried leaf samples were then ground into powder using a clean electric blender. $100 \mathrm{~g}$ of the powdered materials were extracted with water, methanol, ethyl acetate, chloroform and petroleum ether separately using soxhlet apparatus. The extracts were concentrated by evaporating the solvent in rotary evaporator. The yield was found to be $11.30 \%, 15.40 \%, 9.80 \%, 6.90 \%$ and $6.20 \% \mathrm{w} / \mathrm{w}$ respectively with reference to the air dried plant.

\section{Anti inflammatory activity:-}

To test the anti inflammatory activity of leaf extracts of Allophylus serratus three in vitro methods (Human Red Blood Cells stabilization Method (HRBC), inhibition of protein denaturation and protease inhibition) were selected. There reason why these assay methods selected was due to ethical challenges and the nonexistence of rationale to use animals for pharmacological research of new chemical compounds (Bouhlali et al. 2016).

\section{Human Red Blood Cells stabilization Method (HRBC):-}

HRBC stabilization evaluation of the leaf extracts was carried out according to the Gandhisan et al., (1991), Murugan and Parimelazhagan, (2014) and Bouhlali et al. (2016) methods with some modifications. Whole human blood was collected from volunteers (who had not taken any NSAIDS for 2 weeks prior to the experiment) and mixed with equal volume of Alsever's solution which was prepared by dissolving $2 \%$ dextrose, $0.80 \%$ sodium citrate, $0.05 \%$ citric acid and $0.42 \%$ sodium chloride in sterilized double distilled water. The collected blood was mixed with equal volume of sterilized Alsever's solution. The mixture was then centrifuged at $3000 \mathrm{rpm}$ and washed with isosaline. The blood was reconstituted with isosaline and a suspension in $10 \%(\mathrm{~V} / \mathrm{V})$ was made. The assay reaction mixture which is $4.5 \mathrm{~mL}$ consists of $1 \mathrm{~mL}$ phosphate buffer( $(0.15 \mathrm{M}, \mathrm{PH}=7.4), 2 \mathrm{~mL}$ hyposaline $(0.36 \%), 1$ $\mathrm{mL}$ of leaf extracts $(1 \mathrm{mg} / \mathrm{mL}$ of respective organic solvents) and $0.5 \mathrm{~mL} \mathrm{RBC}(10 \% \mathrm{v} / \mathrm{v}$ Red blood cells in isosaline) suspension (Sadique et al., 1989 and Saket et al., 2010). The reaction mixture without the extract was served as a control. The assay mixtures were incubated at $37^{\circ} \mathrm{C}$ for $30 \mathrm{~min}$ and centrifuged and the supernatant solution was estimated using UV analysis at $560 \mathrm{~nm}$. Diclofenac sodium (100 and $200 \mu \mathrm{g} / \mathrm{ml})$ was used as the reference drug. The control which was prepared by omitting the extract represents $100 \%$ HRBC lysis. Percent membrane stabilization activity was calculated by the formula (Sakat et al., 2010; Reshma et al., 2014)

$$
\text { Percent protection }=100-\frac{\mathrm{Ab} 1}{\mathrm{Ab} 2} \times 100
$$

Where $\mathrm{Ab}_{1}$ is the absorbance of the sample, and $\mathrm{Ab}_{2}$ is the absorbance of the control.

\section{Inhibition of Protein denaturation:-}

Inhibition of protein denaturation was evaluated according to the method of Mizushima and Kobayashi (1968), Sakat et al., (2010), Rashma et al., (2014) and Bouhlali et al. (2016) with some modifications. 0.5ml of bovine serum albumin (1\% aqueous solution) was mixed with $0.1 \mathrm{~mL}$ of distilled water. $\mathrm{pH}$ was adjusted at 6.3 using $1 \mathrm{~N}$ HCl. $0.1 \mathrm{ml}$ Allophylus serratus leaf extracts $(\mathrm{mg} / \mathrm{ml}$ of respective organic solvents) was added to the reaction mixture. The mixture was then incubated at $37^{\circ} \mathrm{C}$ for $30 \mathrm{~min}$ and then heated at $51^{\circ} \mathrm{C}$ for $10 \mathrm{~min}$. After cooling the samples to room temperature, $2.5 \mathrm{~mL}$ of phosphate buffer solution (PBS) was added. The absorbance was measured spectrophotometrically at $660 \mathrm{~nm}$. For negative control $0.1 \mathrm{~mL}$ distilled water and $0.5 \mathrm{~mL}$ of bovine serum albumin were used. Acetyl salicylic acid was used as standard. The percentage inhibition of protein denaturation was calculated using the following formula.

$$
\text { Percent inhibition }=\frac{\mathrm{Ab} 1-\mathrm{Ab} 2}{\mathrm{Ab} 1} \times 100
$$

Where $\mathrm{Ab}_{1}$ is the absorbance of the control, $\mathrm{Ab}_{2}$ is the absorbance of the sample. The control represents $100 \%$ protein denaturation. The results were compared with acetyl salicylic acid $(400 \mu \mathrm{g} / \mathrm{ml})$ treated samples. 


\section{Protease inhibition Assay:-}

The Inhibition of protease (trypsin ) was evaluated by the previously reported method of Reshma et al., (201 and Sakat et al., (2010) with some modifications . To $100 \mathrm{ml}$ of bovine serum albumin $100 \mu \mathrm{L}$ of each leaf extract was added. The mixtures were incubated at room temperature for 10 minutes. $250 \mu \mathrm{L}$ of trypsin was added to the mixtures to inhibit the reaction. Then the mixtures were centrifuged at 3000rpm for 5 minutes. The absorbance of the supernatant of each was measured at $210 \mathrm{~nm}$. Acetyl salicylic acid was used as a positive control. Each experiment was done in triplicates and percent inhibition of protease was calculated by the following formula.

$$
\text { Percent inhibition }=\frac{\mathrm{Ab} 1-\mathrm{Ab} 2}{\mathrm{Ab} 1} \times 100
$$

Where $A b_{1}$ is the absorbance of the control, $A b_{2}$ is the absorbance of the sample.

\section{Antimicrobial activity:-}

The extracts were dissolved in DMSO to obtain different concentrations (10mg/ml, $50 \mathrm{mg} / \mathrm{ml}, 100 \mathrm{mg} / \mathrm{ml}$ ) The assay was performed in triplicate. DMSO (10\% in water) was used as negative control. The bacterial strains used for the test were Staphylococcus aureus ( $S$. aureus), Bacillus subtilis (B. subtili), Escherichia coli (E. coli) and Pseudomonas aeruginosa (P. aeruginosa) and the fungal species used were Aspergilus fumigatus (A. fumigates) and Candia albicans (C. albicans).

Four strains of bacteria were procured from microbial culture collection and loops full of all the bacterial cultures were inoculated in LB broth(Luria Bertani broth) (HiMedia) and were incubated at $37^{\circ} \mathrm{C}$ for $24 \mathrm{~h}$. Fresh bacterial cultures were taken and spread on the LB agar(Luria Bertani agar) plates using glass rod to cultivate bacteria. Six millimeter diameter wells were made on agar plate with the help of gel puncture. Twenty micro litters of leaf extracts and DMSO (as control) were inoculated to the well, and then the plates were incubated in incubator at $37{ }^{\circ} \mathrm{C}$ for $24 \mathrm{~h}$. The antimicrobial activity was measured based on the inhibition zone around the wells. The formation of clear inhibition zone of $\geq 7 \mathrm{~mm}$ diameters around the wells was regarded as significant susceptibility of the organisms to the extract (Okwori et al. 2007).

\section{Statistical analyses:-}

All the experiments were done in triplicates and the results were expressed as Mean \pm SD. The data were statistically analyzed using one way ANOVA followed by Duncan's test. Mean values were considered statistically significant when $\mathrm{p}>0.05$.

\section{Results and discussion:- \\ Human Red Blood Cells stabilization Method (HRBC):-}

HRBC membrane stabilization method was used to investigate in vitro anti inflammatory activity of Allophylus serratus leaf extracts. The inhibition of hypotonicity induced HRBC membrane lysis (which is the response of inflammation) stabilization was taken as a measure of the anti inflammatory activity. HRBC membrane may be considered as a model of the lysosomal membrane which plays an important role in inflammation (Weissmann et al., 1969). Lysosomal membrane stabilization is important in limiting the inflammatory responses. The mechanism is by the release of lysosomal constituents of activated neutrophil such as bactericidal enzymes and proteases which cause further tissue inflammation and damage upon extracellular release (Murugasan et al., 1981). HRBC membrane stability test is based on the finding that non-steroidal anti-inflammatory agents inhibit heat induced lysis of erythrocytes, most likely by stabilizing the membrane of the cell.

Compounds in medicinal plants which prevent the lysis of HRBC membrane caused by the release of hydrolytic enzymes contained within the lysosomes may relieve some symptoms of inflammation (Hess and Milonig, 1972). When the HRBC is subjected to hypotonic stress, the release of hemoglobin from cells will be prevented by antiinflammatory compounds in plant extracts due to membrane stabilization. This indicates that some compounds in medicinal plant extracts used as anti inflammatory drug, have the ability to exert anti inflammatory activity (Olajide et al., 2000). The mode of action for membrane stabilization of the plant extracts, may be due to the binding of phytochemical compounds to the HRBC membranes and changing the charges of the surface of the cells (Oyedapo et al., 2010) or according to Shinde et al., (1999) through a deformation of cells by interacting with membrane proteins or other compound in the erythrocyte membranes. This interaction may later provoke alteration of the surface charges of the cells (Oyedapo et al., 2004). Chopade et al., (2012) reported that membrane protective effect of plant extract may be due to their ability to adjust the intracellular concentration of calcium into the erythrocytes. 
For example tannins and saponins show membrane stabilizing effects by binding cations and other biomolecules (Oyedapo et al., 2001).

The percentage of HRBC membrane stabilisation test for leaf extracts and positive control Diclofenac sodium were carried out at concentrations of 100,200,400,800,1000 $\mu \mathrm{g} / \mathrm{ml}$. The percent membrane stabilization and membrane protection of HRBC membrane by Allophylus serratus leaf extracts at different concentrations and positive control Diclofenac sodium are given in Figure 1 and 2. Allophylus serratus leaf extracts at different concentrations showed significant HRBC membrane stabilization. It was observed that methanolic extract of Allophylus serratus leaves exhibited highest membrane stabilizing activity of $77.64 \pm 0.78$ and $74.77 \pm 0.66$ compared to that of standard Diclofenac sodium which exhibited $92.65 \pm 0.56 \%$ and $89.73 \pm 1.18$ at $1000 \mu \mathrm{g} / \mathrm{ml}$ and $800 \mu \mathrm{g} / \mathrm{ml}$ concentrations respectively. The HRBC stabilizing activities of the extracts were concentration dependent, the membrane stabilizing activity increases with increasing concentration. This result is in line with previous report by Nagaharika et al. (2013) who revealed the anti inflammatory activity of leaves of Jatropha gossypifolia which increased with increasing concentration. Murugan and Parimelazhagan, (2014) also reported that methanol extracts of $O$. parvifolia at a concentration of $1 \mathrm{mg} / \mathrm{ml}$ significantly protected the lysis of erythrocyte membrane induced by hypotonic solution which is comparable to the standard Diclofenac sodium.

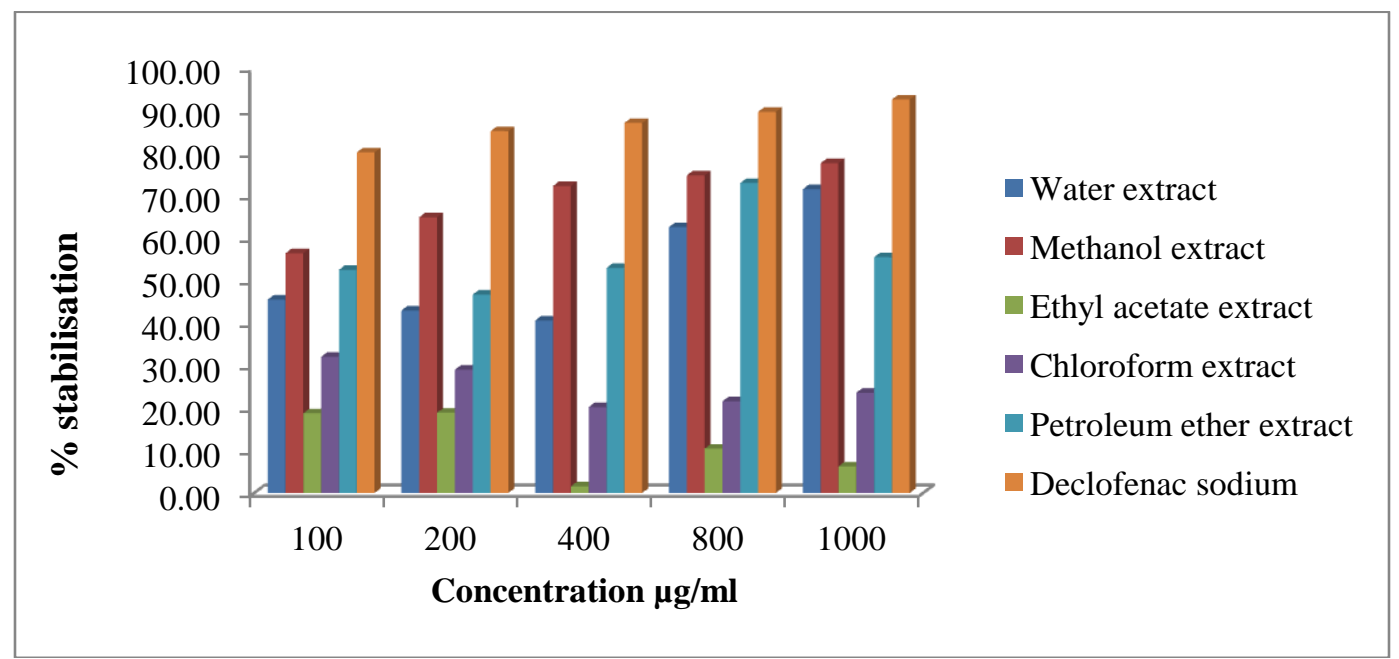

Figure 1:- Percentage of membrane stabilization of leaf extracts of Allophylus serratus.

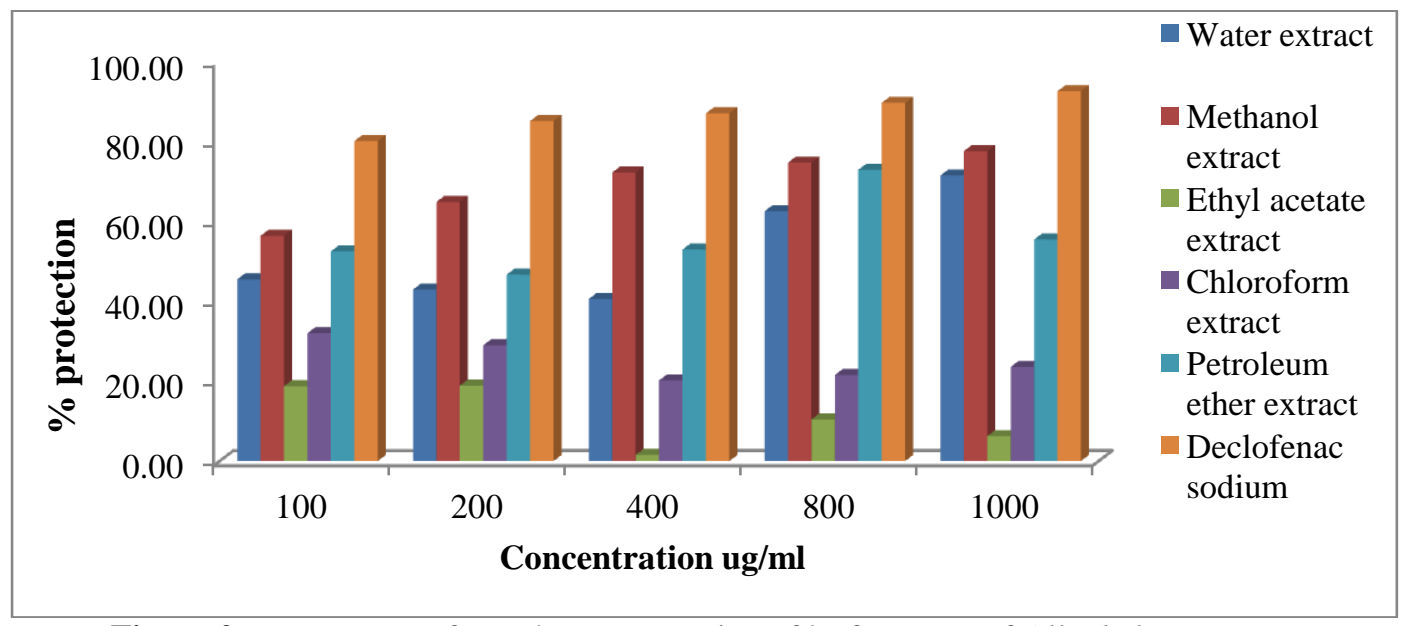

Figure 2:- Percentage of membrane protection of leaf extracts of Allophylus serratus.

\section{Inhibition of Protein denaturation:-}

The body response to infection, injury or destruction is what we call inflammation. Inflammation is characterized by pain, swelling, redness and disturbed physical functions. It is a normal body protective function against injury and 
infection. One of the well documented causes of inflammation is protein denaturation. This is because, most biological proteins lose their function when denatured. The inhibition of protein denaturation by Allophylus serratus leaf extracts were studied by inhibition of protein denaturation method as anti inflammatory activity. The results of inhibitory effect of different extracts of Allophylus serratus leaf on protein denaturation are given in Fig 3 and Table 1. Among the different extracts, methanolic extract at concentrations of $200-1000 \mu \mathrm{g} / \mathrm{ml}$ showed significant percent inhibition which was comparable to the standard Acetyl salicylic acid (93.50\%) at $400 \mu \mathrm{g} / \mathrm{ml}$ (Fig 3). The methanolic extract showed the highest percent inhibition (70.73\%) at $400 \mu \mathrm{g} / \mathrm{ml}$ concentration. More over at 1000 $\mu \mathrm{g} / \mathrm{ml}$ the percent inhibition of protein denaturation increased to $95.93 \%$. The results are in agreement with Murugan and Parimelazhagan, (2014) who reported that methanol extracts of $O$. parvifolia at a concentration of 1 $\mathrm{mg} / \mathrm{ml}$ significantly protected the albumin from denaturation which is comparable to the standard Acetyl salicylic acid. The inhibitory effect was concentration dependent which increases with increasing the concentration of extract from $100 \mu \mathrm{g} / \mathrm{ml}$ to $1000 \mu \mathrm{g} / \mathrm{ml}$. Other studies also revealed that several anti inflammatory drugs also have shown dose dependent inhibition of protein denaturation (Grant et al., 1970; Mizushima and Kobayashi, 1968). The ability of Allophylus serratus to inhibit protein denaturation is presumably due to its anti inflammatory activity.

Table 1:- Percent inhibition of protein denaturation by Allophylus serratus leaf extracts. Each value represents the mean $\pm \mathrm{SD}(\mathrm{n}=3)$. ASA $=$ Acetyl salicylic acid

\begin{tabular}{|c|c|c|c|c|c|c|}
\hline \multirow{2}{*}{$\begin{array}{l}\text { Concentration } \\
(\mu \mathrm{g} / \mathrm{ml})\end{array}$} & \multicolumn{6}{|c|}{$\%$ inhibition } \\
\hline & $\begin{array}{l}\text { Water } \\
\text { extract }\end{array}$ & $\begin{array}{l}\text { Methanol } \\
\text { extract }\end{array}$ & $\begin{array}{l}\text { Ethyl acetate } \\
\text { extract }\end{array}$ & $\begin{array}{l}\text { Chloroform } \\
\text { extract }\end{array}$ & $\begin{array}{l}\text { Petroleum ether } \\
\text { extract }\end{array}$ & $\begin{array}{l}\text { Acetyl } \\
\text { salicylic acid }\end{array}$ \\
\hline 100 & 4.07 & 31.71 & 5.69 & 13.82 & 8.94 & \\
\hline 200 & 8.13 & 41.46 & 10.57 & 16.26 & 18.70 & \\
\hline 400 & 12.20 & 70.73 & 13.01 & 20.33 & 17.89 & 93.50 \\
\hline 800 & 44.72 & 91.06 & 30.08 & 55.28 & 35.77 & \\
\hline 1000 & 69.11 & 95.93 & 58.54 & 65.85 & 58.54 & \\
\hline
\end{tabular}

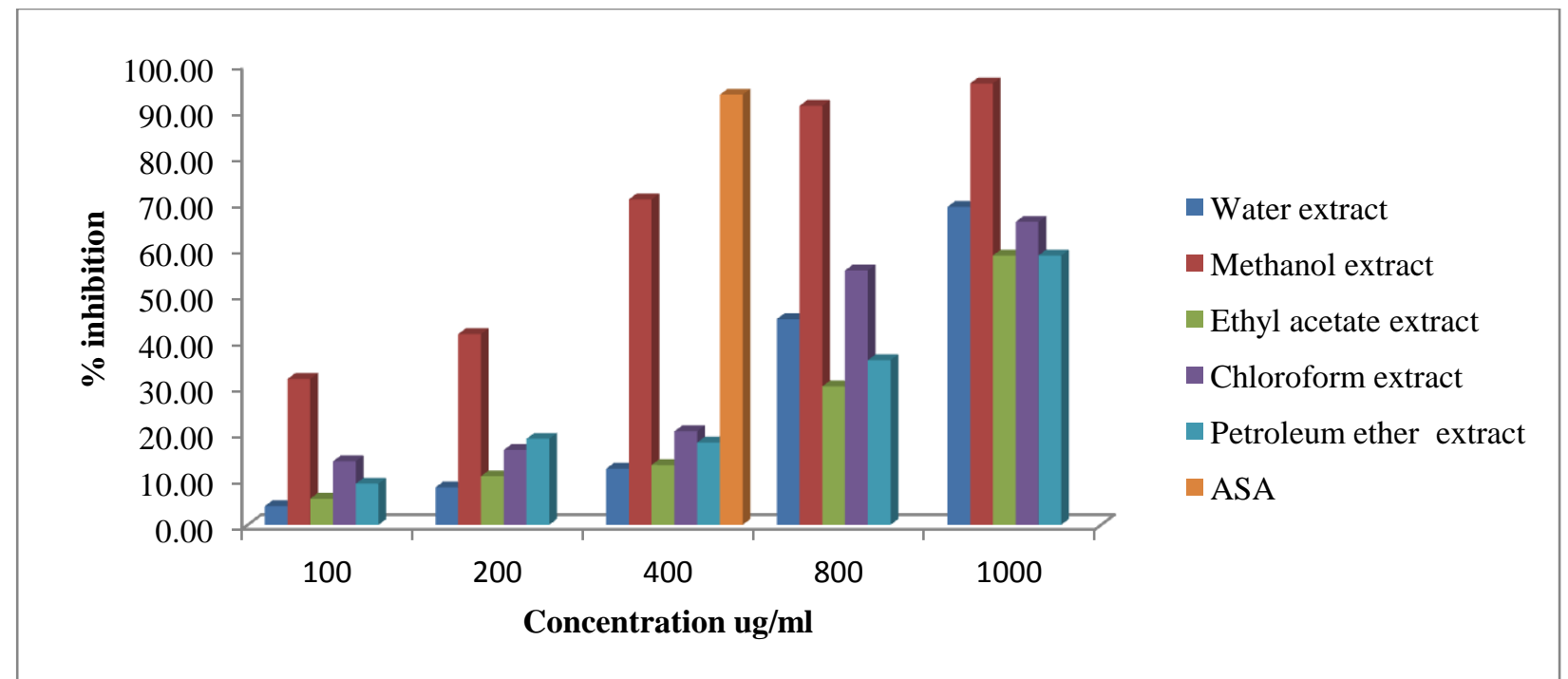

Figure.3:- Percent inhibition of protein denaturation by Allophylus serratus leaf extracts Each value represents the mean $\pm \mathrm{SD}(\mathrm{n}=3)$. ASA= Acetyl salicylic acid

\section{Protease inhibition Assay:-}

During inflammation leukocytes protease enzymes play an important role in tissue damage. Protease inhibitors provide significant protection against this tissue damage developed by proteases during inflammatory reactions (Das and Chatterjee 1995). Phenolic compounds, tannins and flavonoids that are found in medicinal plants have been reported to have anti-inflammatory properties (Amarowicz, 2007). These compounds have the ability to inhibit protease and prevent tissue damage. In the present study Allophylus serratus leaf extracts were tested for their anti inflammatory activity by protease inhibition assay method. The result of this study showed that ethyl acetate extract has the highest protease inhibition activity compared to other extracts. The ethyl acetate extract produced the highest percentage inhibition $(67.63 \%)$ at $100 \mu \mathrm{g} / \mathrm{ml}$ concentrations. The protease inhibitory action was dose dependent with 
the greater inhibitory effect of $81.02 \%$ at $1000 \mu \mathrm{g} / \mathrm{ml}$. Chloroform and methanol extracts at $1000 \mu \mathrm{g} / \mathrm{ml}$ also showed significant protease inhibitory activity $76.39 \%$ and $75.42 \%$ respectively Fig 4 .

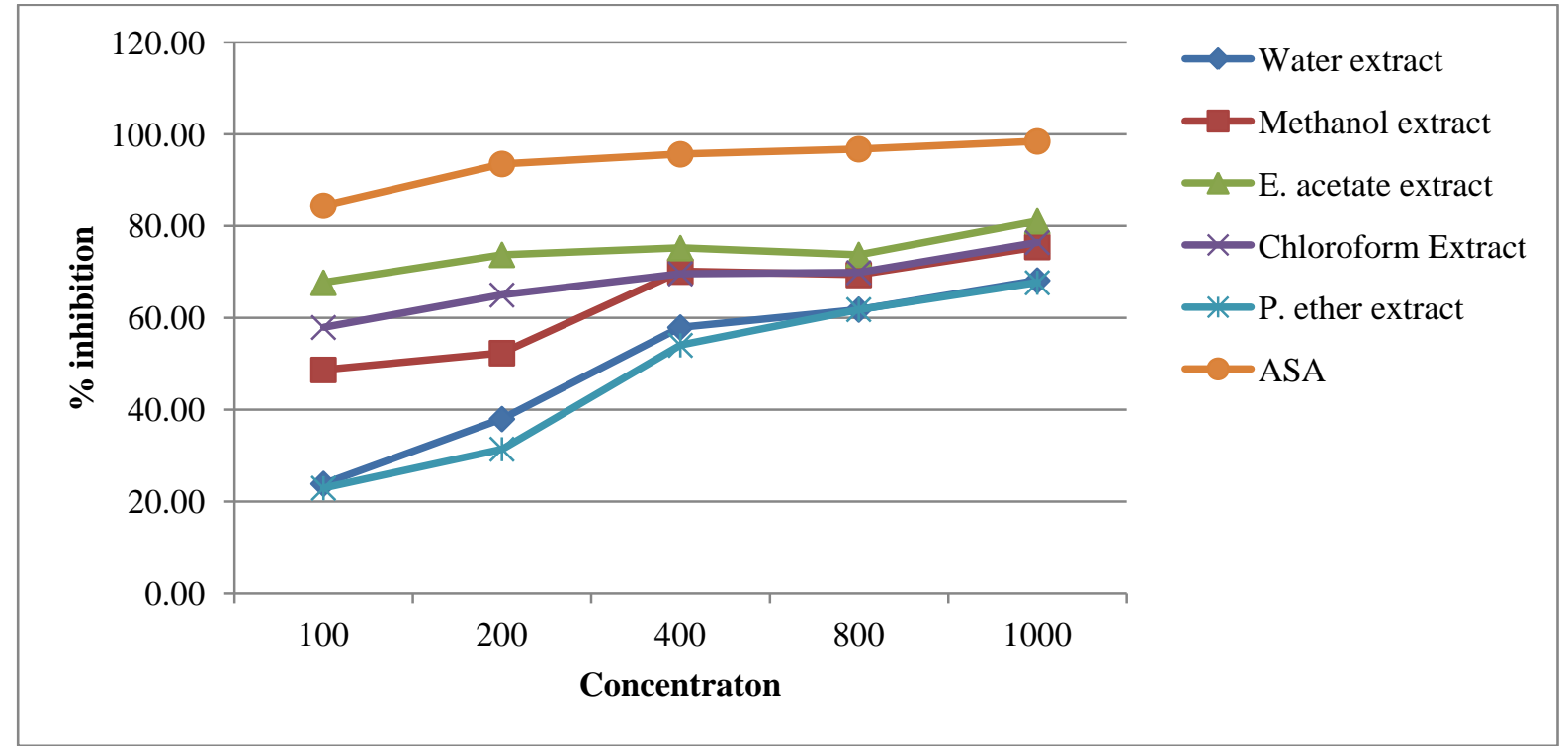

Figure 4:- Percent protease inhibition by Allophylus serratus leaf extracts Each value represents the mean \pm SD ( $\mathrm{n}=3$ )

The anti inflammatory activity assay of different solvent extracts of Allophylus serratus leaf by HRBC membrane stabilization, inhibition of protein denaturation and protease inhibition produced promising results. The possible reason for the anti inflammatory activities of the plant is the presence of Phenolics, flavonoids, tannins and saponins which have anti inflammatory activity (Oyedapo, 2001). The in vitro anti-inflammatory effect of plant material may be due to synergistic effect rather than single constituent of their polyphenols contents (Bouhlali et al. 2016). This study also showed that the type of solvent used in extraction is important to find polyphenolic compounds from plant extracts. Comparison of these five solvents revealed that, they produce different anti inflammatory activities. Overall, methanolic extract, water extract and ethyl acetate extract were found to be good in obtaining antiinflammatory substances from the extracts than the others.

\section{Antimicrobial activity:-}

An agar well diffusion assay method was used to determine the antimicrobial effects of the extracts of the leaves of Allophylus serratus against four strains of bacteria (E. coli, B. subtilis, S. aureus and P. aeruginosa) and two strains of fungi A. fumigates and C. albicans. The results of antimicrobial activity test are given in Table 2 and Fig 5. The results revealed variability in the inhibitory effect of each extracts against tested bacteria and fungi.

Table 2:- Antimicrobial activity of the different extracts of the leaves of Allophylus serratus on selected bacterial and fungal species

\begin{tabular}{|c|c|c|c|c|c|c|}
\hline \multirow{2}{*}{$\begin{array}{l}\text { Microbial } \\
\text { strain }\end{array}$} & \multicolumn{6}{|c|}{ Zone of Inhibition (mm) } \\
\hline & $\begin{array}{l}\text { Water } \\
\text { extract }\end{array}$ & $\begin{array}{l}\text { Methanol } \\
\text { extract }\end{array}$ & $\begin{array}{l}\text { Ethyl acetate } \\
\text { extract }\end{array}$ & $\begin{array}{l}\text { Chloroform } \\
\text { extract }\end{array}$ & $\begin{array}{l}\text { Petroleum ether } \\
\text { extract }\end{array}$ & $\begin{array}{l}\text { Contr } \\
\text { ol }\end{array}$ \\
\hline E. coli & $18 \pm 0.01$ & $14 \pm 0.12$ & $15 \pm 0.04$ & - & - & - \\
\hline S. aureus & $23 \pm 0.23$ & $18 \pm 0.25$ & $13 \pm 0.01$ & - & - & - \\
\hline B. sabtilis & - & - & $20 \pm 0.00$ & - & - & - \\
\hline P. aeruginosa & - & - & - & $20 \pm 0.17$ & $22 \pm 0.09$ & - \\
\hline A. fumigates & - & - & - & - & - & - \\
\hline C. albicans & - & - & - & - & - & - \\
\hline
\end{tabular}

The water, methanol and ethyl acetate extracts displayed low activity against the B.sbtilis and P. aeruginosa except the ethyl acetate extract which showed high activity against $B$. sabtilis $(20 \pm 0.00 \mathrm{~mm})$. The water extract displayed high activity against $S$. aureus $(23 \pm 0.23 \mathrm{~mm})$. The water extract, methanol extract and ethyl acetate extract were 
slightly more active against E.coli $(18 \pm 0.25,141 \mathrm{nd} 15 \mathrm{~mm}$ respectively). Chloroform and petroleum ether extracts inhibited the growth of $P$. aeruginosa $(20 \pm 0.17$ and $22 \pm 0.09 \mathrm{~mm}$ respectively) but no activity against the rest tested bacterial strains (Table 2). Under the concentrations and conditions tested, Chloroform and petroleum ether extracts were active against Gram-negative bacterial strain ( $P$. aeruginosa). On the other hand no any extract of Allophylus serratus showed anti fungal activity against tested strains of fungi (A. fumigates and C. albicans ).
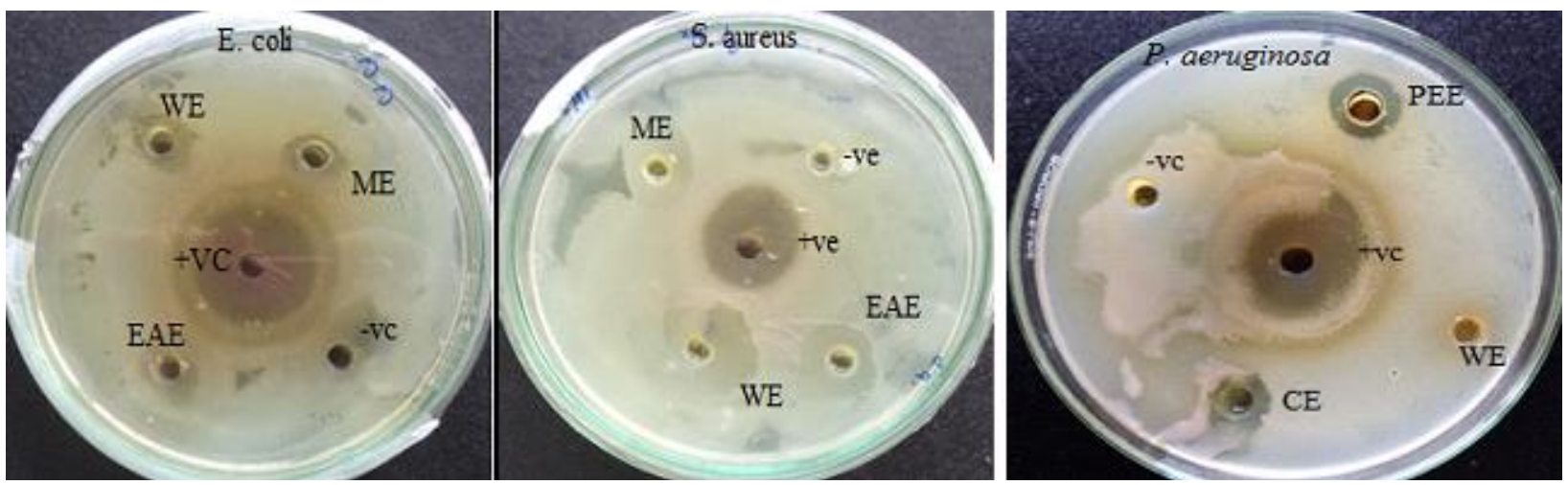

Figure 5:- Antimicrobial activity of Allophylus serratus leaf extracts. $-\mathrm{vc}=$ negative control, $=\mathrm{vc}=$ positive control, $\mathrm{WE}=$ water extract, $\mathrm{ME}=$ methanol extract, $\mathrm{EAE}=$ Ethyl acetate extract, $\mathrm{CE}=$ Chloroform extract, $\mathrm{PEE}=\mathrm{Petroleum}$ ether extract.

The antibacterial activity of plant extracts as recorded in previous studies is attributed to the phytochemicals such as flavonoids, alkaloids and tannins present in plants. For example flavonoids in plants have antimicrobial (Maria Lysete et al., 2009) and antiviral (Mehrangiz] et al., 2011) properties. Alkaloids isolated from plant are also found to have antimicrobial properties (Ahmed et al., 2010). Tannins have antibacterial activity and kill bacteria by damaging its cell membrane (Mohamed Sham et al., 2010). (Arokiyaraj et al., (2009) reported that seeds extracts of Vitex agnus-castus has antimicrobial activity due to the presence of alkaloids, saponins, tannins, flavonoids, and glycosides contents.

Allophylus serratus as reported in previous studies also contain phytochemicals such as saponins, tannins, flavonoids and glycosides (Sanmuga et al., 2012). There for the antibacterial activity of Allophylus serratus leaves extracts may be attributed to the presence of the phytochemicals reported to be present in it.

\section{Conclusion:-}

The anti inflammatory activity assay of Allophylus serratus leaves extracts exhibited membrane stabilization hypotonicity induced lysis of erythrocyte membrane, protein denaturation and protease inhibition effects. The plant extracts also showed significant anti bacterial activities against different bacterial strains. This implies that the extracts have significant anti inflammatory and anti bacterial activity compared to the standard medicines. The presence of various phytochemicals such as alkaloids, polyphenols tannins, saponins and flavonoids may be responsible of these activities. Therefore the results of this study provides scientific base for the traditional use of this plant as anti inflammatory and antibacterial agent. These results also showed that Allophylus serratus could be a potential natural source of compounds which have greater importance as therapeutic agent in inflammation related disorders and bacterial infections. Further studies are required to identify and isolate the active components of the extracts responsible for their anti-inflammatory properties and their mode of action.

\section{References:-}

1. Agyare C, Asase A, Lechtenberg M, Niehues M, Deters A, et al., (2009) An ethnopharmacological survey and in vitro confirmation of ethnopharmacological use of medicinal plants used for wound healing in BosomtwiAtwimaKwanwoma area, Ghana. J Ethnopharmacol 125: 393-403.

2. Agyare C, Dwobeng AS, Agyepong N, Boakye YD, Mensah KB, et al. (2013) Antimicrobial, Antioxidant, and Wound Healing Properties of Kigelia africana (Lam.) Beneth. and Strophanthus hispidus DC. Adv Pharmacol Sci : 692613.

3. Ahamad, I., et al., (1998) Screening of some Indian medicinal plants for their antimicrobial properties. Journal of Ethno pharmacology, 62:183-193. 
4. Ahmed el-HM, Nour BY, Mohammed YG, Khalid HS. (2010) Antiplasmodial activity of some medicinal plants used in Sudanese folk-medicine. Env Health Insts;4(4):1-6.

5. Amarowicz, R. (2007.) Tannins: the new natural antioxidants? Eur. J. Lipid Sci. Technol. 109, 549-551.

6. Arokiyaraj S, Perinbam K, Agastian P, Kumar RM. (2009) Phytochemical analysis and antibacterial activity of Vitex agnus-castus. Int J Green Phar.;3(2):162-164.

7. Battu GR, Ethadi SR, Veda PG, Swathi PK, Chandrika K, Rao VA, et al. (2011) Evaluation of antioxidant and anti inflammatory activity of Euphorbia heyneana Spreng. Asian Pac JTro Biomed;S191-4.

8. Das SN and Chatterjee S. (1995) Long term toxicity study of ART-400. Indian Indg. Med ;16(2): 117-123

9. Davis, J., (1994) Inactivation of the antibiotics and the dissemination of resistance genes. Science, (Vol.264):375-382.

10. Devi, A. G., Shyma, T. B. and Raghavendra, M. P (2013) Plants used by the tribes for the treatment of digestive system disorders in Wayanad district, Kerala. Journal of Applied Pharmaceutical Science, 3 (8): 171-175

11. Dharmani P., Palit G. (2006) Exploring Indian Medicinal plants for anti ulceractivity. Indian J Pharmacol; 38 (2): $95-9$

12. Doughari JH, El-mahmood AM, Tyoyina I. (2008) Antimicrobial activity of leaf extracts of Senna obtusifolia (L) Afr J Pharm Pharmacol; 2:7-13.

13. Bouhlali E, , Sellam K. , Bammou M. , Alem C. , Filalizehzouti Y., (2016) In vitro Antioxidant and antiinflammatory properties of selected Moroccan medicinal plants. Journal of Applied Pharmaceutical Science 6 (05); 156-162

14. Gandhisan, R., Thamaraichelvan, A., Baburaj. (1991) Antiinflammatory action of Lannea coromandelica Hrbc membrane stabilization. Fitotherapia.62, 82- 83.

15. Grant NH, Alburn HE, Kryzanauskas C. (1970) Stabilization of serum albumin by anti-inflammatory drugs. Biochem. Pharmacol. 1970; 19:715 -722.

16. Gupta AK, Tandon N. (2004) Reviews on Indian Medicinal Plants. Vol 2. New Delhi: Indian Council of Medical Research.

17. Hess SM, and Milloning RC. (1972) Inflammation, Mechanism and Controll, Lepow LH and Wards PA, Eds Academic press New York, 1-72.

18. Kumar, M., P. Rawat, P. Dixit, D. Mishra and A.K. Gautam et al., (2010) Antiosteoporotic constituents from Indian medicinal plants. Phytomed., 179: 93-99.

19. Iwu M W, Duncan A R, Okunji C O. (1999) New antimicrobials of plant origin. In: Janick J (Eds), Perspectives on new crops and new uses, ASHS Press, Alexandria, VA 457-462.

20. Karuppiah P. and Mustaffa M. (2013) Antibacterial and antioxidant activities of Musa sp. leaf extracts against multidrug resistant clinical pathogens causing nosocomial infection. Asian Pacific Journal of Tropical Biomedicine, vol. 3, no. 9, pp. 737-742.

21. Maria Lysete AB, Maria Raquel FL, et al. (2009) Studies on the antimicrobial activity and brine shrimp toxicity of Z. tuberculosa extracts and their main constituents. Annals of Clil Microb Antimic;8:16.

22. Umashanker M. and Shruti S. (2011) Traditional indian herbal medicine used as antipyretic, antiulcer, antidiabetic and anticancer: a review. international journal of research in pharmacy and chemistry. issn: 2231-2781

23. Mehrangiz KK, Seyed AE, Masoud SG, Esmaeel AS, Amirhossein S. (2011) Antiviral activities of aerial subsets of Artemisia species against Herpes Simplex virus type 1 (HSV1) in vitro. Asian Biomed;5(1):63-68.

24. Mizushima Y, Kobayashi M. (1968) Interaction of anti-inflammatory drugs with serum proteins, especially with some biologically active proteins. J Pharm Pharmacol ;20(3):169-73.

25. Mohamed Saleem TK, Azeem AK, Dilip C, Sankar C, PrasanthNV, Duraisami R. (2011) Anti-inflammatory activity of the leaf extacts of Gendarussa vulgaris Nees. Asian Pac J Trop Biomed ; 147-149.

26. Mohamed Sham Shihabudeen H, Hansi Priscilla D, Kavitha T., 2010. Antimicrobial activity and phytochemical analysis of selected Indian folk medicinal plants. Int J of Pharma Sci Res;1(10):430-434.

27. Murugan R. and Parimelazhagan T. (2014) Comparative evaluation of different extraction methods for antioxidant and anti-inflammatory properties from Osbeckia parvifolia Arn.-An in vitro approach. J King Saud Univ Sci; 26(4): 267-275.

28. Murugasan N, Vember S and Damodharan C. (1981) Studies on erythrocyte membrane IV. Invitro haemolytic activity of Oleander extract. Toxicol. Lett ; 8:33- 38 .

29. Nascimento GGF, Lacatelli J, Freitas PC, Silva GL. (2000) Antibacterial activity of plant extracts and phytochemicals on antibiotic-resistant bacteria. Braz. J. Microbiol. 31(4): 886-891.

30. Okwori AEJ, Dina CO, Junaid S, Okeke IO, Adetunji JA, Olabode AO. (2007) Antibacterial activities of Ageratum conyzoides extracts on selected bacterial pathogens. Internet J Microbiol; 4(1) doi: 10.5580/fce. 
31. Olajide O.A., Makinde J.M., Okpako D.T., Awe S.O. (2000) Studies on the anti-inflammatory and related pharmacological properties of the aqueous extract of Bridelia ferruginea stem bark. Journal of Ethnopharmacology 71: 153-160.

32. Oyedapo, O.O. (2001) Biological activity of Plyllanthus amarus extracts on pragrow-Dawley rats. Nig. J. Biochem. Mol. Biol., 83-86

33. Rastogi RP, Mehrotra BN. (1995) Compendium of Indian Medicinal Plants. Vol 4. New Delhi: Publication and Information Directorate; 58-89.

34. Reshma, Arun KP, Brindha P. (2014) In vitro anti-inflammatory, antioxidant and nephroprotective studies on leaves of Aegle marmelos and Ocimum sanctum. Asian j Pharm Clin Res, 7 (4): 121-129.

35. Sadique J, Al-Rqobahs WA, Bughaith, EI-Gindi AR. (1989) The bioactivity of certain medicinal plants on the stabilisation of RBS membrane system. Fitoterapia ;60:525-32

36. Sakat S, Juvekar AR, Gambhire MN. (2010) In vitro antioxidant and antiinflammatory activity of methanol extract of Oxalis corniculata Linn. Int J Pharm Pharm Sci;2(1):146-5

37. Sanmuga Priya E., Senthamil Selvan P. and Tamilselvan R., 2012. Phytochemical Investigation of Allophylus serratus Kurz Leaves by UV and GC-MS Analysis. Research Journal of Phytochemistry, 6: 17-24.

38. Weissmann, G., Spilberg, I., and Krakauer, K. (1969) Arthritis induced in rabbits by lysates of granulocyte lysosomes. Arthritis and Rheumatism, 12, 103-116.

39. Nagaharika Y., Kalyani V., Rasheed S, Skarthikeyan R., (2013) Anti-inflammatory activity of leaves of Jatropha gossypifolia L. by hrbc membrane stabilization method. Journal of Acute Disease, 156-158

40. Shinde UA, Phadke AS, Nair AM, Mungantiwar AA, Dikshit VJ and Saraf VO. (1999). Membrane stabilizing activity-a possible mechanism of action for the antiinflammatory activity of Cedrus deodara wood oil. Fitoterapia 70: 251-257.

41. Oyedapo, O.O., B.A. Akinpelu, K.F. Akinwumi, M.O. Adeyinka and F.O. Sipeolu (2010). Red blood cell membrane stabilizing potentials of extracts of Lantana camara and its fractions. Inter. J. Plant Physiol. Biochem. 2 (4): 46-51.

42. Oyedapo OO, Akinpelu BA, Orefuwa SO. (2004) Anti-inflammatory effects of Theobroma cacao, L. root extract. J. of Tropical Med. Plants (Malaysia) 5(2):161-166

43. Chopade AR, Sontakke PM and Sayyad FJ. (2012) Membrane stabilizing activity and protein denaturation: A possible mechanism of action for the anti-inflammatory activity of Phyllanthus amarus. Journal of Karad Institute of Medical Sciences University 1 (1) 67-72. 